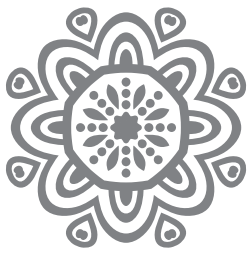

\title{
Tafsir Kontekstual dalam Penetapan Awal Bulan Hijriyah Antara Hisab dan Ruyah
}

\author{
Abdur Rokhim \\ Dosen Institut Perguruan Tinggi Ilmu al-Quran (PTIQ) Jakarta. Kontak hp 08158949619
}

\begin{abstract}
Asbtrak: Salah satu problem klasik dalam Islam adalah terkait penetuan awal bulan hijriyah. Perbedaan penentuan awal hijriyah khususnya penetapan 1 Ramadhan dan 1 Syawal misalnya, kerap terjadi perbedaan. Realita demikian, bermula dari proses penetapan antara yang menggunakan hisab dan ru'yah. Perbedaan dua hal tersebut dikalangan umat Islam, bukan tanpa dalil atau landasan dari teks-teks al-Qur'an dan hadis. Problem demikian, tulisan ini mengkrucutkan antara metode hisab dan ru'yah dengan upaya kontekstualisasi terhadap teks al-Qur'an dan hadis yang dijadikan legitimasi dalam penetapan awal bulan Hijriyah.
\end{abstract}

\section{Kata Kunci: Hisab, Ru'yah, Kontekstualisasi.}

\section{A. Pendahuluan}

Umat Islam di Indonesia selalu dihadapkan pada perbedaan pendapat dalam penentuan awal Ramadhan, 1 syawal (idul fitri) dan 'idul adhha. Perbedaan pendapat pada umumnya dapat dinilai sebagai rahmat, namun ada juga perbedaan yang dinilai sebagai adzab. Ada hadits yang menjelaskan tentang perbedaan, yaitu hadits "ikhtilaf ummati rahmah"1 اختلاف أمتي رحمة (perbedaan ummatku adalah rahmat) dan hadits lain: اختلاف أصحابي رحمة لأمتي (perbedaan sahabat-sahabatku adalah rahmat bagi ummatku) kedua hadits ini diriwayatkan oleh al-Baihaqi dalam kitabnya al-Madkhal. Al-Thabarani dan al-Dailami juga ikut

${ }^{1}$ Jalaluddin Abdurrahman bin Abu Bakr As-Suyuthi, Al-Fath Al-Kabir fi Dham Az-Ziyadah ila Al- Jami' Al-Kabir, (Beirut, Dar Al-Fikr, 1423 H), Cet. Ke-1, Juz 1, h. 54. Menurut Imam As-Suyuthi: Hadits ini diriwayatkan pleh Nashr Al-Muqaddasi dalam kitabnya al-Hujjah, dan oleh Al-Baihaqi dalam kitabnya ar-Risalah Al-Asy'ariyah, tanpa sanad, sedangkan Al-Hulaimi, Al-Qadhi Husain, dan Imam Al-Haramain dan ulama hadits yang lain menuliskan hadits ini dalam kitabnya. 
meriwatkan hadits ini. Hadits ini statusnya adalah dha'if sebagaimana dijelaskan oleh al-Sakhawi dalam kitabnya al-maqashid al-hasanah ${ }^{2}$.

Walaupun kedua hadits itu statusnya dhaif, tetapi secara substansi dibenarkan oleh al-Qur'an, karena al-Qur'an memberikan petunjuk, bahwa perbedaan umat manusia dalam segala hal dan perbedaan pendapat di kalangan ulama dalam menafsirkan al-Qur'an merupakan keniscayaan dan sunnatullah. al-Qur'an memberikan petujuk akan hal itu, terbukti dengan adanya lafazh-lafazh mutasyabihat dalam al-Qu'an (lafazh-lfazh yang samar atau tidak jelas ma'nanya) dan banyak lafazh-lafazh yang memiliki màna zhanni ad-dalalah (tidak pasti ma'na yang dimaksud).

Perbedaan pendapat tidaklah harus mengarah kepada perpecahan, perselisihan dan pertentangan, bahkan permusuhan. Selama perbedaan pendapat itu disertai dengan sikap toleran, dan dilandasi kesadaran bahwa perbedaan pendapat itu merupakan keniscayaan, sebagaimana al-Qur'an memberikan peluang akan terjadinya perbedaan pendapat dalam memahaminya. Sedangkan yang dikecam oleh al-Qur'an adalah pertentangan dan perselisihan yang mengarah kepada permusuhan. Tidak mungkin al-Qur'an melarang perbedaan pendapat, karena itu akan melanggar kudrat al-Qur'an itu sendiri.

Imam an-Nawawi menjelaskan bahwa perbedaan pendapat dalam agama (Islam) itu tebagi menjadi tiga macam :

1. Dalam hal eksistensi Tuhan (Allah) dan mentauhidkan-Nya, mengingkari akan hal ini dan perbedaan dalam hal ini bisa menjadikan kafir.

2. Dalam hal sifat-sifat Allah dan kehendaknya, mengingkarinya adalah bid'ah.

3. Perbedaan dalam hukum-hukum far'i (cabang) yang mengandung banyak interpretasi, maka dalam hal ini Allah menjadikannya sebagai rahmat dan kemulyaan bagi para ulama, itulah yang dimaksud dengan Hadits لأمتي 3

Ibnu Taimiyah mengatakan, bahwa perbedaan terkadang dapat mendatangkan rahmat dan terkadang mendatangkan adzab. Perbedaan hukum bisa jadi rahmat apabila tidak mendatangkan keburukan besar seperti samanya hu$\mathrm{kum}^{4}$.

${ }^{2}$ Muhammad Ibn Abdurrahman al-Sakhawi, al-Maqashid al-Hasanah fi Bayan Katsir mi al-Ahadits al-Musytahirah 'ala al-Alsinah, (Beirut, Dar al-Kitab al-Arabi ) Juz I, h. 69.

${ }^{3}$ Abu Zakaria Yahya Ibn Syaraf al-Nawawi, Syarh Shahih Muslim, (Beirut, dar Ihya' al-Turats al-Arabi, $1392 \mathrm{H}$ ), Juz 5, h. 27.

${ }^{4}$ Wuzarah al-Auqaf wa al-Syu'un al-Islamiah bi-alKuwait, al-Mausu'ah al-Fiqhiah. Al-Kuwaitiyah, Juz 2 h. 673. 
Perbedaan pendapat ulama, ada yang memiliki implikasi terhadap masalah sosial ada yang tidak. Sejalan dengan pendapat itu, maka dapat juga dikatakan bahwa perbedaan yang tidak membawa dampak negatif terhadap sosial budaya, maka berarti perbedaan yang baik, akan tetapi perbedaan yang membawa danpak negatif terhadap social, maka ini bisa merupakan perbedaan yang negative, bisa pula disebut azab. Perbedaan pendapat ulama dalam hal apa, hukum apa, dan atau masalah apa yang dapat berdampak negatif terhadap sosial umat? Perbedaan pendapat ulama dalam menetapkan hukum ibadah terbagi 3 (tiga) macam :

1. badah yang dilaksanakan secara pribadi.

2. Ibadah yang dilaksanakan dengan melibatkan orang lain, seperti shalat berjama’ah.

3. Ibadah yang dilaksanakan dengan melibatkan masyarakan luas dan pemerintah.

1.a. Ibadah yang dilaksanakan secara pribadi, seperti shalat fardhu yang dilaksanakan secara sendiri, atau shalat sunnah, puasa sunnah, dzikir, membaca al-Qur'an dan lain-lainnya, tidak berdampak sosial.

2.a. Ibadah yang dilaksanakan dengan melibatkan orang lain, seperti shalat berjamaa'ah, memiliki dampak sosial, walaupun dalam sekup yang kecil.

3.a. Ibadah yang dilaksanakan dengan melibatkan masyarakat luas dan pemerintah, seperti ibadah shalat idul fitri, shalat idul adhha, juga puasa ramadhan, yang harus ditetapkan awal mulainya pada awal bulan oleh pemerintah, maka ibadah seperti ini memiliki dampak sosial yang sangat luas. Perbedaan pendapat ulama tentang ibadah seperti ini akan menimbulkan dampak sosial yang sangat besar.

Penetapan hari raya idul fitri dan idul adhha memiliki dampak sosial yang sangat besar. Oleh karena itu, perbedaan dalam hal ini bisa jadi merupakan azab bukan rahmat. Dalam perbedaan yang seperti ini sebaiknya dan semestinya dapat disatukan agar dapat mendatangkan kemaslahatan buat umat. Ulama telah menetapkan kaidah fiqhiyah terkait dengan perbedaan yang berdampak negatif seperti ini, yaitu hukm al-hakim yarfa' al-khilaf ${ }^{5}$ (keputusan hakim menghapus perbedaan).

${ }^{5}$ Abdur Rahman Al-Jaziri, al-Fiqh ala al-Madzahib al-Arba’ah, Juz 1, h. 877. Lihat juga ; Wahbah az-Zuhaili, al-Fiqh al-Islami wa Adillatuh, (Damaskus, Dar al-Fikr, tth), Cet. Ke-4, Juz 3, h. 39 . 
Masalah berikutnya adalah: Apakah yang menyebabkan Perbedaan pendapat di kalangan ulama dalam penetapan awal bulan hijriah, kaitannya dengan penetapan awal puasa ramadhan, idul fitri dan idul adhha ? Benarkah bahwa perbedaan penentuan awal bulan sangat erat kaitannya dengan penafsiran dalil-dalil dalam al-Qur'an maupun Hadits ? mungkinkah umat Islam disatukan dalam penentuan awal bulan, mengingat bahwa permasalahan penentuan awal buan juga sangat terkait dengan sains, ya'ni ilmu hisab (ilmu falak), astronomi dan fisika. Ilmu ini dapat dikategorikan ilmu yang pasti ? permasalahan inilah yang akan dibahas.

\section{B. Sejarah Perhitungan Bulan}

Mengapa Islam Memakai Kalender Bulan (bukan matahari) ? Sejak awal peradaban, manusia sudah merasakan perlunya sistem pembagian waktu menjadi satuan-satuan periode "bulan" dan "tahun" yang lazim disebut Kalender atau Taqwim (Arab). Kebutuhan manusia akan sistem kalender itu berkaitan dengan kepentingan kehidupan sehari-hari mereka, dan atau kepentingan

kehidupan keagamaan mereka. Acuan yang digunakan untuk menyusun kalender atau taqwim tersebut, adalah siklus pergerakan dua benda langit yang sangat besar pengaruhnya pada kehidupan manusia di Bumi, yakni Bulan dan Matahari. Kalender yang disusun berdasarkan siklus sinodik Bulan dinamakan Kalender Bulan (Qamariyah, Lunar). Kalender yang disusun berdasarkan siklus tropik Matahari dinamakan Kalender Matahari (Syamsiyah, Solar). Sedangkan kalender yang disusun dengan mengacu kepada keduanya dinamakan Kalender Bulan-Matahar (Qamariyah-Syamsiyah,Luni-Solar).

Sekitar empat ribu tahun lebih, sebelum masehi, bangsa Arab telah membuat Kalender Matahari atau Syamsiyah. Pada waktu itu tahun Syamsiyah terdiri dari 365 hari dengan rincian 360 hari dibagi menjadi 12 bulan dengan umur masing-masing 30 hari, dan 5 hari untuk pesta perayaan tahunan bangsa Arab.

Belakangan Kalender Syamsiyah itu digunakan juga oleh masyarakat Romawi. Bangsa Arab sendiri kemudian beralih pada Kalender Bulan atau Qamariyah yang digunakan juga oleh masyarakat Mesir kuno dan Babilonia. Kalender Qamariyah $\neg$ Syamsiyah digunakan oleh orang-orang Cina dan India. Islam yang datang untuk pertama kalinya kepada masyarakat Arab mengukuhkan penggunaan kalender qamariyah yang telah berlaku di kalangan mereka itu dengan cara mengaitkan waktu pelaksanaan beberapa ketentuan syariahnya kepada kalender tersebut serta membuat sistemnya menjadi mapan. Islam -misalnya- memapankan konsep "bulan" (syahr, month) dalam kalender tersebut sebagai periode waktu yang membentang di antara dua penampakan hilal be- 
rurutan, dan "tahun" (sanah) sebagai periode waktu yang terdiri dari dua belas "bulan". Ketika orang-orang kafir menyisipkan tambahan bulan untuk menunda masuknya bulan Muharram, al-Qur'an (at-Taubah: 37) mengecamnya dengan menegaskan bahwa perbuatan mereka itu hanyalah menambah kekafiran belaka.

Dalam kalender qamariyah, umur bulan (syahr) bisa diketahui dengan mudah melalui pengamatan yang sederhana terhadap Bulan. Hal itu terkait dengan sunnatullah tentang siklus pergerakan Bulan yang membuat Bulan hadir dalam pengamatan manusia di Bumi dalam posisi dan bentuk penampakan yang selalu berubah setiap hari secara signifikan. Perubahan itu berupa pergeseran posisinya ke arah Timur sejauh rata-rata $13^{\circ}$ setiap hari atau setara dengan 26 kali garis tengah piringannya, dan pergeseran itu sekaligus mengakibatkan perubahan bentuk penampakannya. Mengenai fenomena ini Al-Qur' an (Yasin: 39) menyatakan: "Kami tetapkan bagi Bulan manzilah-manzilah, sehingga kembalilah dia sebagai bentuk tandan yang tua."

Keadaan seperti itu tidak terjadi pada Matahari yang hadir dengan bentuk penampakan yang relatif sama setiap hari. Meskipun sebenarnya posisi Matahari itu juga bergeser, yakni ke Utara atau ke Selatan, tetapi pergeserannya itu terjadi tidak secara mencolok, karena per hari rata-rata hanya sebesar $0^{\circ} 15^{\prime} 24,54^{\prime \prime}$, atau hanya setengah kali garis tengah piringannya. Karena itu -tidak seperti dalam kalender qamariyah- umur bulan dalam kalender syamsiyah tidak bisa dengan mudah diketahui lewat pengamatan yang sederhana terhadapMatahari. Dengan penghampiran ini dapatlah dipahami kalau Nabi SAW memberi petuniuk kepada kaum muslimin generasi awal-yang masih Ummi- untuk memulai dan mengakhiri puasa Ramadhan berdasarkan ru'yat atau pengamatan terhadap penampakan Hilal. Dengan gambaran sebagaimana telah dikemukakan, perintah ru'yat tersebut tentu menjadi tidak relevan seandainya Islam menjatuhkan pilihannya pada kalender "syamsiyah"

Sudah menjadi kesepakatan, bahwa penetapan awal bulan hijriyah adalah dengan terbitnya hilal. Hilal adalah bulan sabit yang terbit pertama kali. Tentang hilal menjadi tanda datangnya awal bulan dijelaskan oleh al-Qur'an "Mereka bertanya kepadamu tentang bulan sabit (hilal). Katakanlah: "bulan sabit (hilal) itu adalah tanda-tanda waktu bagi manusia dan (bagi ibadah) haji..” (Q.S.al-Baqarah: 189) dan hadits Nabi "jangan kamu (mulai) berpuasa (ramadhan) sehingga kamu melihat hilal dan jangan kamu melaksanakan idul fitri sehingga kamu melihat hilal, apabila tertutup mendung, maka perkirakanlah" ${ }^{6}$ (H.R. Bukhori)

${ }^{6}$ Muhammad Ibn Ismail al-Bukhari, shahih al-Bukhari, (Beirut, Dar Ibn Katsir, $1407 \mathrm{H}$ ) Juz 2, h. 674 


\section{Perhitungan Kalender Hijriyah dengan menggunakan Bulan (Rembulan)}

Bulan mengorbit bumi selama 27 hari, 7 jam, 43 menit, dan 11 detik. Kata "qamar" dalam bahasa arab, berarti "bulan", digunakan sebanyak 27 kali oleh al-Qur'an. Orbit bulan yang mengelilingi bumi membentuk gris yang berliku-liku. Sementara bumi bergerak mengelilingi matahari, bulan beredar mengelilingi bumi dalam orbit yang berbeda-beda, membentuk garis yang melengkung, berkelok-kelok, berbentuk spiral. Permukaan bulan yang menghadap ke bumi selalu sama. Garis melengkung yang dibentuknya mengingatkan kita pada tandan yang melengkung. Kata dalam bahasa arab yang digunakan untuk menunjukkan orbit bulan adalah "urjun", yaitu tandan kurma yang melengkung. Tandan ini ditambahkan dengan kata tua yang menggambarkan tandan yang lebih tipis dan melengkung. Kiasan yang indah ini menggambarkan orbit yang dilalui bulan dalam mengelilingi bumi.

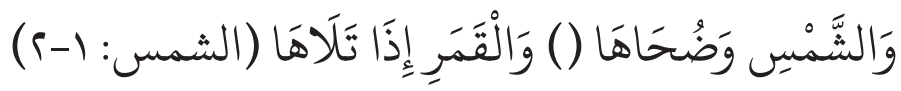

"demi matahari dan cahayanya di pagi hari, dan bulan apabila mengiringinya (Q.S. Asy-Syams: 1-2)

Pada ayat di atas terlihat gambaran hubungan bulan dengan matahari. Kata "tala" dalam bahasa arab berarti "pengikut", "yang bergantung". Sebagai satelit bumi, bulan beredar menglilingi matahari bersama-sama dengan bumi, mereka mengikuti jejak matahari. Baik bulan maupun bumi bergantung pada pergerakan matahari.

Al-Qur’an juga menjelaskan :

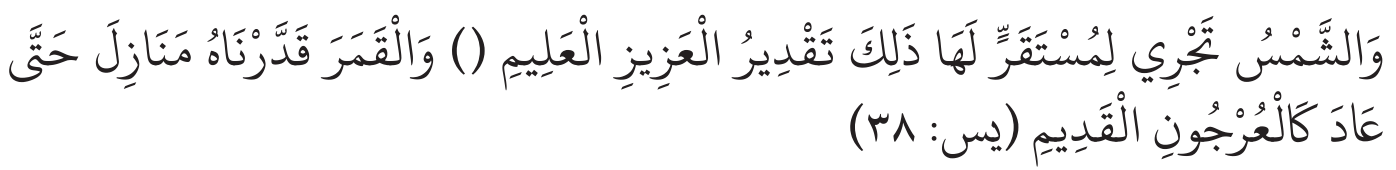

"Dan matahari berjalan di tempat peredarannya. Demikianlah ketetapan Yang Maha Perkasa lagi Maha Mengetahui. Dan telah kami tetapkan bagi bulan manzilah-manzilah, sehingga (setelah dia sampai ke manzilah yang terakhir) kemabalilah dia sebagai bentuk tandan yang tua.(Q.S. Yasin: 3839)

Dalam tafsir ad-Durr al-Mantsur As-Suyuthi menafsirkan ayat tersebut, dengan meriwayatkan beberapa atsar (perkataan sahabat dan tabi'in), di لوقتها ولأجلٍ لا تعدوه : لوال 
(untuk waktunya dan batas yang tidak dilampauinya), kemudian manafsirkan ayat 39 mengutip riwayat al-Khatib dari Ibn Abbas, berkata: rembulan memiliki 28 manzilah setiap bulannya: Empat belas (14) manzilah di antaranya adalah asy-Syamiyah, yaitu: 1. As-Sirthin (awalnya). 2. Al-bithin. 3. Ats-tsurayya. 4. Ad-dabran. 5. Al-haq'ah. 6. Al-han'ah. 7. Adz-dzira'. 8. An-natsrah. 9. Ath-tharf. 10. Al-jabhah. 11. Az-zabrah. 12. Ash-sharfah. 13. Al-'awa'. 14. As-samak (akhirnya). Empat belas (14) manzilah lainnya adalah al-yamaniyah, yaitu: 1. Al-'aqrab (awalnya). 2. Az-zabanin. 3. Al-iklil. 4. Al-qalb. 5. Asy-syaulah. 6. An-na'aim. 7. Al-baldah. 8. Sa'd adz-dzabih. 9. Sa'd bal'. 10. Sa'd as-su'ud. 11. Sa'd al-akhbiyah. 12. Muqaddam ad-dalw. 13. Mu'akhkhar ad-dalw. 14. Al-hut (akhirnya). Apabila ke 28 manzilah ini telah dilalui maka kembali seperti di awal bulan. ${ }^{7}$

Muhammad Sayyid Thanthawi juga menjelaskan dalam tafsirnya, bahwa rembulan memiliki 28 manzilah (tempat perjalanannya atau rotasinya), tetapi tidak menyebut nama-nama manzilah, yang dimuali dari awal bulan dan berakhir pada tanggal 28, kemudian yang 1 hari atau 2 hari yang lain (bila bulan genap 30 hari) tertutup. ${ }^{8}$ Berapakah bilangan hari dalam sebulannya? . Banyak hadits-hadits Nabi yang menjelaskan jumlah hari dalam sebulan, ada yang menyebutkan 29 hari dan ada yang 30 hari, sebagaimana hadits-hadits tersebut di atas dan hadits-hadits berikut :

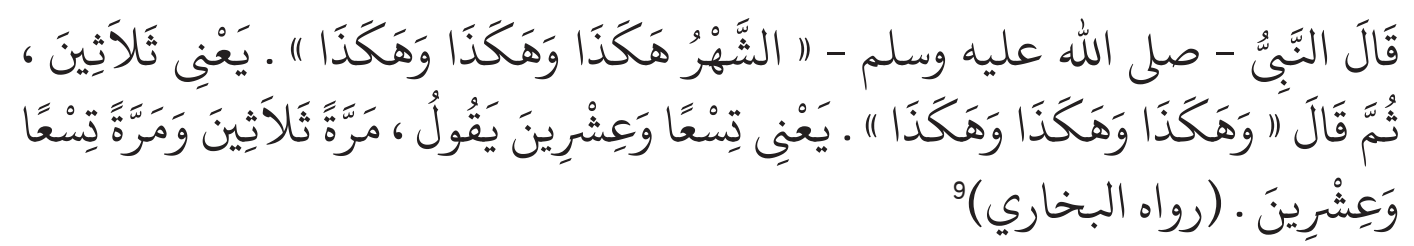

"Rasulullah saw. Bersabda: bulan itu begini, begini, dan begini. Ya'ni 30 hari. Kemudian bersabda: dan begini, begini, dan begini, ya'ni 29 hari” (H.R. Bukhari)

Juga hadits berikut:

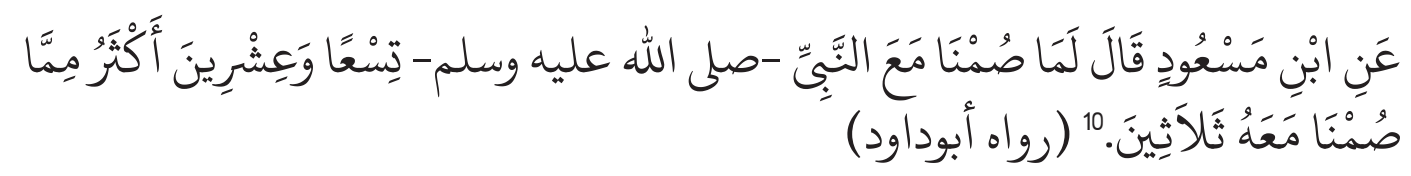

${ }^{7}$ As-Suyuthi, ad-durr al-mantsur fi at-ta'wil bi al-ma'tsur, ( Beirut, Dar al-Fikr, 1993), Juz 4, h. 302

${ }^{8}$ Muhammad Sayyid Thanthawi, at-Tafsir al-Wasith, Juz 1, h. 353.

${ }^{9}$ Muhammad Ibn Isma’il al-Bukhari, Shahih al-Bukhari, Beirut, Dar Ibn Katsir, 1987 M), Juz4, h. 203.

${ }^{10}$ Sulaiman Ibn Al-Asy'ats Abu Daud, Sunan Abu Daud, (Beirut, Darul Fikr, tth), Juz 1, h. 710. 
Ibnu Mas’u berkata: ketika saya berpuasa besama Nabu Muhammad saw. Maka jumlah bulan terdiri dari 29 hari itu lebih banyak daripada 30 hari." (H.R. Abu Daud)

\section{Sebab Perbedaan Penentuan Awal Bulan Hijriah}

Sudah puluhan bahkan ratusan tahun lamanya perdebatan mengenai perhitungan penentuan awal bulan pada bulan hijriyah. Terlebih pada penentuan awal bulan syawal (idul fitri) atau idul adha yang berkaitan dengan hari raya umat islam. Khususnya bagi umat islam, setidaknya harus paham mengenai kenapa perbedaan ini harus terjadi..? karena nikmat dari perbedaan bukan pada pertenkaran tapi keberagaman.

Perbedaan yang tejadi di antara para ulama pada umumnya mengerucut pada dua hal, yaitu: metode hisab dan ru'yah.

Perbedaan pendapat dalam memahami kata "ru'yah" di dalam hadis “... shumu li ru'yatihi wa althiru li ru'yatihi ..." (Berpuasalah kamu ketika melihat hilal (awal bulan Ramadan). Berbukalah kamu ketika melihat hilal (awal bulan Syawal). Pendapat pertama, (kelompok rukyah) berpendapat yang dimaksud dengan kata "ru'yah" adalah melihat hilal secara fisik (ru'yah bil fili). Pendapat ini didasarkan kepada dua alasan. Pertama, Rasulullah dan para sahabat selalu melihat hilal untuk menentukan awal dan akhir Ramadan. Kedua, adanya indikasi bahwa jika hilal tidak terlihat --- karena mendung --- maka hitungan bulan Sya’ban dan Ramadan harus disempurnakan (30 hari), sebagaimana hadist yang disebutkan di atas. Sedangkan Pendapat kedua, yaitu kelompok hisab menafsirkan "ru'yah" dengan ru'yah bil 'ilmi (melihat dengan ilmu). Pendapat kelompok ini didasarkan atas tiga hal.

Pertama, ayat Alquran surat Yunus (10:5)

"Dia-lah yang menjadikan matahari bersinar dan bulan bercahaya dan ditetapkan-Nya manzilah-manzilah (tempat-tempat) bagi perjalanan bulan itu, supaya kamu mengetahui bilangan tahun dan perhitungan (waktu). Allah tidak menciptakan yang demikian itu melainkan dengan hak[669]. dia menjelaskan tanda-tanda (kebesaran-Nya) kepada orangorang yang Mengetahui." (Yunus, 10:5)

Dalam ayat tersebut menganjurkan kepada umat Islam mempelajari peredaran matahari dan bulan sebagai dasar penghitungan waktu dan tahun (li'ta'lamu 'adad al sinina wa al hisab). Ayat inilah yang menjadi pijakan lahirnya Ilmu Hisab (Falaq). Ilmu ini digunakan secara sangat luas untuk menentukan 
waktu salat dan kalender Hijriyah, awal akhir bulan, hari raya (Idul Fitri - Idul Adha), wukuf di Arafah dan ibadah lainnya.

Kedua, tradisi melihat hilal yang dilakukan oleh Rasulullah dan sahabat hanyalah merupakan "cara" yang dilakukan karena keterbatasan ilmu pengetahuan dan teknologi. Karena itu, umat Islam bisa menggunakan "cara" lain yang diisyaratkan oleh Alquran. Di antaranya dengan cara ilmiah melalui penghitungan Falaq/ Hisab/Perhitungan. Ilmu ini baru berkembang pada masa Bani Abbasiyah (abad ke-8 M). Pada masa Rasulullah belum ditemukan alat teropong bintang dan belum berkembang ilmu falaq/ astronomi

Ketiga, kelompokhisab berpendapatawal dan akhirbulan tidakditentukan oleh beberapa derajat ketinggian hilal. Jika berdasarkan penghitungan hisab hilal sudahnampak, berapapunketinggiannya, makahitunganbulanbarusudah masuk.

Karena itu, jika hilal bulan Syawal sudah masuk maka sudah saatnya Idul Fitri. Sedangkan kelompok rukyah berkeyakinan jika posisi hilal sangat rendah, dia tidak bisa di-ru'yah atau terlihat dengan mata telanjang. Karena itu hitungan Ramadan harus disempurnakan (istikmal) 30 hari. Di sinilah sumber perbedaan penentuan Idul Fitri.

Perbedaan penentuan awal bulan hijriah disebabkan dua hal pokok: Pertama: perbedaan penafsiran teks-teks al-Qur'an maupun Hadits yang terkait dengan Hisab dan Ru'yah. Sebagian menafsirkannya secara tekstual. Sedang sebagian yang lain menafsirkannya secara kontekstual. Kedua: Metode yang digunakan dalam penetuan ulan.

\section{E. Metode Hisab dan Ru'yah dalam Penentuan Hilal}

Di Indonesia telah lama berkembang, bahkan menjadi perbedaan yang relatif tajam, di kaqlangan umat islam, tentang penentuan hilal dalam penetapan awal bulan hijriyah, terutama yang terkait dengan penetapan awal ramadhan, idul fitri, idul adhha. Sebagian umat islam menggunakan metode ru'yah, sedangkan sebagian yang lain mengunakan metode hisab dalam menentukan hilal sebagai tanda tanda awal bulan.

\section{Hilal}

Hilal secara bahasa adalah bulan yang nampak pada malam pertama sampai malam ketiga di setiap bulannya dan setelah itu barulah dikatakan bulan (tidak dikatakan lagi hilal, pent). ${ }^{11}$ Dalam bahasa Indonesia hilal dikenal sebagai bulan sabit.

\footnotetext{
${ }^{11}$ Al-Razi, Mukhta al-Shihah, (Beirut, Maktabah Lubnan Nasyirun, 1415), juz I, h. 705.
} 
Ada yang berpendapat sampai 3 (tiga) malam, bahkan ada yang mengatakan sampai 7 (tujuh) malam pertama dari setiap bulan.Menurut Abi Ishaq dan banyak pendapat yang lain, bahwa yang disebut hilal itu adalah tanpaknya bulan pada malam pertama dan kedua dari setiap bulan, karena pada malam ketiga cahaya bulan sudah terang. ${ }^{12}$ Allah swt. menjelaskan fungsi hilal dalam al-Qur'an:

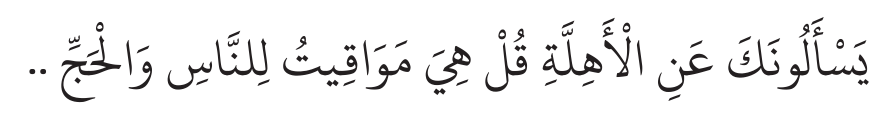

"mereka bertanya kepadamu tentang bulan sabit. Katakanlah: "Bulan sabit itu adalah tanda-tanda waktu bagi manusia dan (bagi ibadat) haji(Q.S al-Baqarah: 189)

Hilal adalah keadaan bulan pada waktu muncul pertama di awal bulan. Bulan disebut hilal pada kemunculannya malam pertama dan kedua di awal bulan dan dua malam terakhir di akhir bulan. Hilal merupakan batas waktu bulan, maka disebut mawaqit, adalah bentuk jama' dari miqat. Rasulullah saw. Menjelaskan hilal sebagai pedoman dalam melaksanakan ibadah puasa dengan langsung malihatnya atau 'ru'yah'

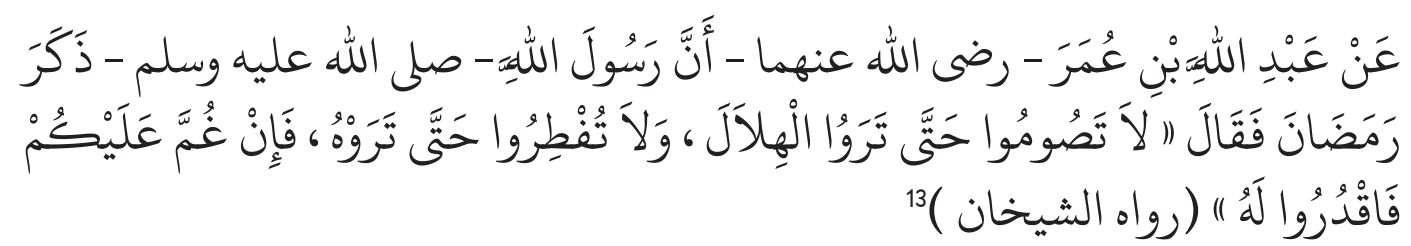

Dari Abdullah Ibn Umar r.a. Rasulullah saw. Menjelaskan Ramadhan,maka ia berkata: "Kalau kalian melihat hilaal (awal Ramadhan, -pent) maka berpuasalah, dan jika kalian melihatnya (hilal tanda masuk bulan Syawwal) maka berbukalah (idul fitri). Dan jika (pandangan) kalian terhalangi oleh awan,kalian menghitungnya!" (H.R. Bukhari, Muslim dan An-Nasa'i)

Dalam hadits yang lain, Rasulullah saw. Bersabda :

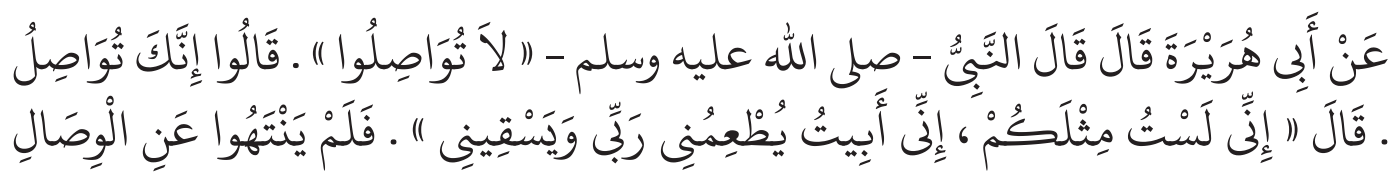

${ }^{12}$ Murtadha Al-Zabidi, Taj al-Arus min Jawahir al-Qamus, (Darul Hidayah, tth), Juz 31 h. 144.

${ }^{13}$ Muhammad Ibn Isma'il al-Bukhari, Shahih al-Bukhari, (Beirut, Dar Ibn Katsir, 1987 M), Juz 2, h. 674 


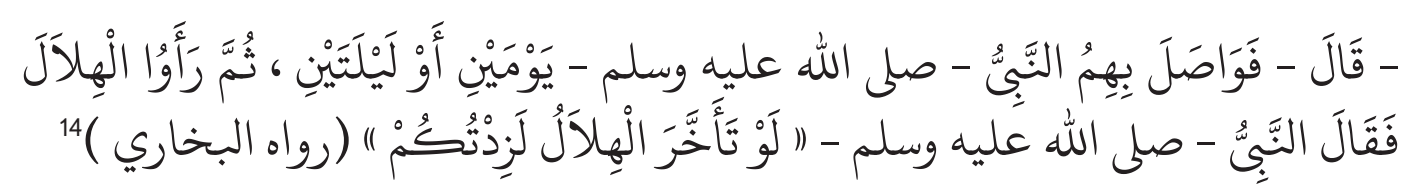

"Dari Abu Hurairah r.a. berkata, Rasulullah saw. Bersabda "jangan kamu melaksanakan puasa wishal (menyambung puasa). Sahabat berkata: engkau melakukan wishal. Rasulullah besabda: Saya tidak sama dengan kamu. Saya selalu diberi makan dan minum oleh Allah swt. maka mereka tidak sampai wishal. Abu Hurairah mengatakan: maka Rasulullah saw. Melaksanakan puasa wishal 2 hari atau 2 malam. Kemudian mereka melihat hilal, lalu Rasulullah saw. Besabda: seandainya kemunculan hilal mundur, maka saya akan tambahkan kepadamu (H.R. Bukhari)

\section{Hisab}

Salah satu ilmu pengetahuan yang sangat penting bagi ummat Islam adalah ilmu hisab atau ilmu falak. Ilmu hisab ini sangat berkaitan dengan ibadah penting yaitu shalat, puasa dan haji. Dengan ilmu hisab, waktu shalat fardhu dapat ditentukan dengan tepat dan pasti melalui pergerakan matahari. Sementara pergerakan matahari itu sendiri telah ditentukan posisinya. Allah SWT berfirman

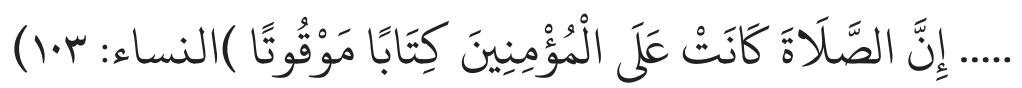

"Sesungguhnya shalat itu adalah fardhu yang ditentukan waktunya atas orang-orang yang beriman." (An-Nisa: 103)

Penentuan masuknya bulan Ramadhan, Syawal dan Dzulhijjah sebagai patokan untuk ibadah puasa dan haji dapat diprediksi dengan memahami pergerakan matahari dan bulan. Selain itu, dengan sedikit memahami ilmu matematika bola, arah Ka'bah yang menjadi kiblat shalat dapat pula diketahui dari segala posisi di bumi. Mengingat pentingnya ilmu hisab, maka ilmu ini sangat perlu dipelajari oleh ummat Islam.

Secara bahasa, kata "hisab" berasal dari haasaba - yuhaasibu - muhaasabatan - hisaaban. Kata hisab berarti perhitungan. Ilmu hisab memang bermakna ilmu untuk menghitung posisi benda langit (matahari, bulan, planet-planet dan lain-lain). Yang memiliki akar kata yang sama dengan kata "hisab" adalah kata "husban" yang berarti perhitungan. Kata "husban" disebutkan dalam Al Qur'an

${ }^{14}$ Muhammad Ibn Isma'il al-Bukhari, Shahih al-Bukhari, tahqiq Musthafa Dib al-Bigha, (Beirut, Dar Ibn Katsir, 1987 M), Juz 4, h. 2661. 
untuk menyatakan bahwa pergerakan matahari dan bulan itu dapat dihitung dengan ketelitian sangat tinggi.

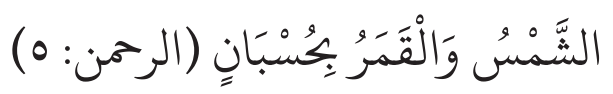

"Matahari dan bulan (beredar) menurut perhitungan." (Ar-Rahman:5)

Ilmu ini memiliki kaitan erat dengan astronomi. Namun secara umum ilmu hisab hanya mengambil bagian kecil dari astronomi yaitu mempelajari pergerakan matahari, bulan, bumi serta planet-planet lain di tata surya (solar system). Dengan mempelajari ilmu hisab, kita akan dapat menentukan arah qiblat, waktu sholat, serta posisi matahari dan bulan setiap saat. Selain itu, kalender Islam dapat pula dihitung, sehingga masuknya bulan-bulan penting dalam Islam seperti Muharram, Ramadhan, Syawal dan Dzulhijjah dapat diperkirakan. Dengan ilmu hisab, berbagai peristiwa alam yang menakjubkan seperti gerhana matahari, gerhana bulan, transit Merkurius dan Venus di matahari dapat pula dihitung dengan akurasi tinggi. Dan masih banyak lagi fenomena yang dapat ditelusuri melalui ilmu hisab ${ }^{15}$.

Kata hisab yang mengandung arti perhitungan (matahari dan bulan) atau terkait dengan ilmu hisab terdapat pada empat (4) Surah, yaitu: kata husban terdapat pada Surah al-An'am: 96 dan Surah Al-Qamar: 5. Kata hisab terdapat pada Surah Yunus: 5 dan Al-Isra': 12.

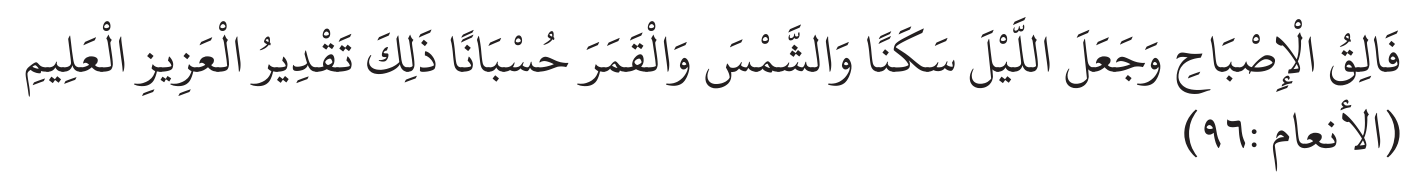

"Dia menyingsingkan pagi dan menjadikan malam untuk beristirahat, dan (menjadikan) matahari dan bulan untuk perhitungan. Itulah ketentuan Allah yang Maha Perkasa lagi Maha mengetahui (Q.S. Al-An'am: 96).

Ayat ini ditafsirkan oleh al-Razi ${ }^{16}$ bahwa Allah swt. Telah menetapkan ukuran gerakan matahari dan bulan dengan perhitungan tertentu sebagaimana dijelaskan pada Surah Yunus: 5 dan Surah al-Rahman: 5 . Allah swt. Telah menetapkan ukuran pergerakan matahari pada kecepatan tertentu sehingga sempurna perputaran dalam setahun. Dan juga menetapkan ukuran pergerakan bulan dengan kecepatannya sehingga menjadi sempurna dalam perputarannya dalam

\footnotetext{
${ }^{15}$ Rinto Anugraha, Pengantar Ilmu Hisab, http://rukyatulhilal.org/artikel/rinto-pengantar-ilmu-hisab.html diakses tgl 23-09-2011

${ }^{16}$ Fakhruddin Al-Razi, Mafatih Al-Ghaib, Juz 6, h. 932.
} 
sebulan. Dengan ukuran pergerakan dan kecepatannya yang telah ditentukan oleh Allah swt. Maka akan berpengaruh kepada kebaikan alam.

Al-Kholil Ibn Ahmad ${ }^{17}$ menjelaskan ma’na husban yang ada pada Surah al-Rahman: 5 dalam kitabnya al-Ain :

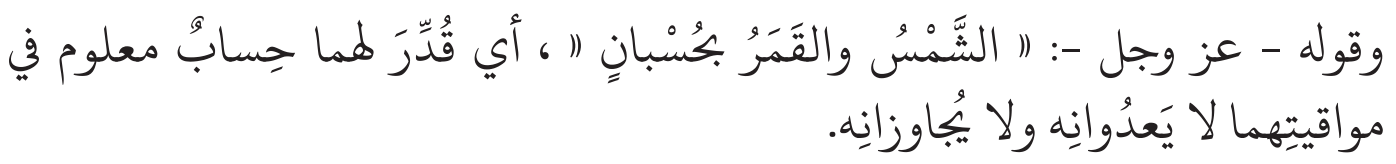

"ya’ni ditetapkan bagi kedua matahari dan bulan suatu perhitungan yang pasti dalam waktu-waktu yang keduanya tidak akan melampaunya.

Juga ayat berikut in $\mathrm{i}$ :

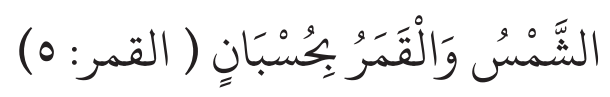

"matahari dan bulan (beredar) menurut perhitungan(Q.S. Al-Qamar: 5).

Sedangkan kata hisab digunakan pada 2 ayat berikut :

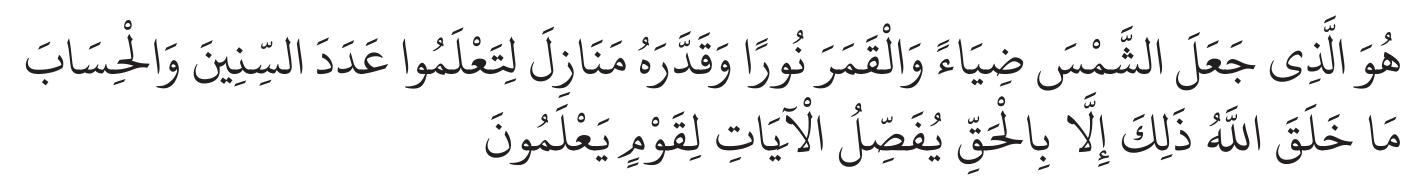

"Dia-lah yang menjadikan matahari bersinar dan bulan bercahaya dan ditetapkan-Nya manzilah-manzilah (tempat-tempat) bagi perjalanan bulan itu, supaya kamu mengetahui bilangan tahun dan perhitungan (waktu). Allah tidak menciptakan yang demikian itu melainkan dengan hak[669]. Dia menjelaskan tanda-tanda (kebesaran-Nya) kepada orangorang yang mengetahui.(Q.S. Yunus: 5)

Dan Firman Allah swt. berikut :

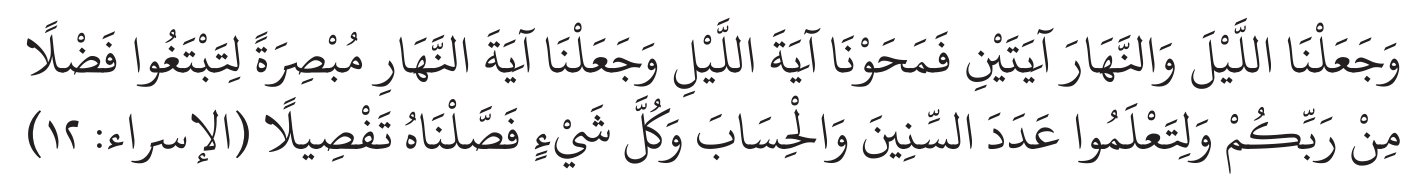

"dan Kami jadikan malam dan siang sebagai dua tanda, lalu Kami hapuskan tanda malam dan Kami jadikan tanda siang itu terang, agar kamu mencari kurnia dari Tuhanmu, dan supaya kamu mengetahui bilangan tahun-tahun dan perhitungan. dan segala sesuatu telah Kami terangkan dengan jelas." (Q.S al-Isra': 12)

${ }^{17}$ Al-Kholil Ibn Ahmad, Al-'Ain Juz 1, h. 200

Mumtäz Vol. 1 No. 2, Tahun 2017 131 
Dua ayat tersebut menjelaskan, bahwa Allah swt menciptakan orbit-orbit yang dilalui matahari dan bulan, begitu pula diciptakannya malam dan siang secara silih berganti, maka dapat diketahui bilangan tahun dan perhitungan waktu, yảni perhitungan waktu dalam setahun, bilangan hari dan jam. ${ }^{18}$

Tentang hisab, Rasulullah saw. menjelaskan dalam sebuah hadits berikut:

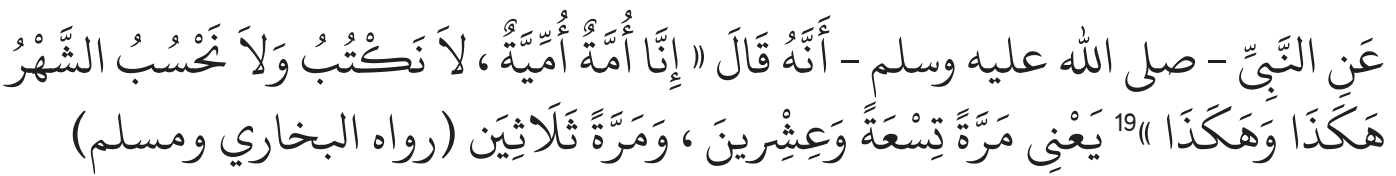

"Dari Nabi Muhammad saw. berkata: sesungguhnya kami adalah ummat yang ummi, tidak bisa menulis dan menghitung, bulan itu bilangannya begini, begini (dengan isyarat tangan), ya'ni sekali waktu 29 hari dan sekali temo 30 hari (H.R. Bukhari)

Ibnu Hajar Al-Asqalani menjelaskan, bahwa yang dimaksud al-hisab (terambil dari kata wa la nahsuba) pada hadits tersebut di atas adalah perhitungan bintang dan perjalananya. Bangsa arab atau sahabat Nabi saat itu tidak mengasainya kecuali sebagian sedikit di antara mereka, maka hukum berpuasa dan lainnya digantungkan atas ru'yah untuk meringankan mereka dan menjauhkan dari kesulitan perhitungan perjalanan atau pergrakan bintang. Hukum ru'yah menjadi pedoman seperti itu terus berjalan, walaupun sesudah itu ada di antara umat Islam yang menguasai ilmu hisab, bahkan menurut zahir redaksi hadits memberikan pengertian tidak menggantungkan hukum puasa dan lainnya kepada ilmu hisab. Hal ini sebagaimana dijelaskan pada hadits yang lain "maka apabila dalam keadaan mendung maka sempurnakanlah hitungan bulan 30 hari” dan Rasulullah saw. Tidak mengatakan 'bertanyalah kamu kepada ahli hisab'.

Hikmah yang dapat diambil dari hal tesebut adalah, bahwa hitungan bulan ketika dalam keadaan mendung maka menjadi sama bagi seluruh mukallaf, maka hilanglah perbedaan dan pertentangan. Sebagian ulama dari rafidhah berpendapat , agar tetap kembali kepada ahli hisab. ${ }^{20}$ Juz 15 , h. 23

${ }^{18}$ Ibn Jarir Al-Thabari, Jami’ al-Bayan fi Ta’wil al-Qur’an, ( Muassasah al-Risalah, 1420), Juz 2, h. 675.

${ }^{19}$ Muhammad Ibn Isma'il al-Bukhari, Shahih al-Bukhari, (Beirut, Dar Ibn Katsir, 1987 M),

${ }^{20}$ Ibn Hajar Al-Asqalani, Ftah al-Bari Syarh Shahih al-Bukhari, (Beirut, Dar al-Ma'rifah, 1379), Juz 4, h. 127. 
Mustafa Dib al-Bigha menjelaskan hadits tersebut, sama dengan penjelasan Ibn Hajab al-Asqalani, bahwa yang dimaksud wa la nahsubu adalah: kami tidak mengethui perhitungan nujum, maka umat Islam dalam menetapkan waktu-waktu ibadah tidak dibebani untuk mengetahui ilmu hisab dan tulis. ${ }^{21}$

Untuk mengetahui perhitungan bulan dengan menggunakan bulan atau matahari dapat diketahui dengan ilmu falak, hisab dan astronomi.

Falak berarti: [n] (1) lengkung langit; lingkaran langit; cakrawala; (2) pengetahuan mengenai keadaan (peredaran, perhitungan, dsb) bintang-bintang; ilmu perbintangan; astronomi ${ }^{22}$. Pengertian falak secara populer adalah lintasan benda-benda angkasa (langit), dalam bahasa Inggris disebut ORBIT.

Ilmu Falak adalah ilmu pengetahuan yang mempelajari lintasan benda-benda langit, seperti Matahari, Bulan, Bintang-bintang, dan benda-benda langit lainnya, dengan tujuan untuk mengetahui posisis dari benda-benda langit itu sendiri serta kedudukannya dari benda-benda langit lainnya, agar dapat diambil manfaatnya bagi manusia, khsususnya umat islam dalam menentukan waktu untuk beribadah.Secara umum Ilmu Falak mempelajari 4 hal, yaitu:

1. penentuan Arah Qiblat dalam Sholat

2. Penentuan Waktu-waktu Sholat

3. Penentuan Awal bulan kalender Hijriyah

4. Penentuan terjadinya Gerhana Matahari dan Bulan.

Hisab artinya perhitungan. Ilmu Hisab ialah ilmu yang mempelajarai perhitungan posisi benda-benda langit secara matematis dan astronomis khususnya untuk keperluan Ibadah. Astronomi berasal dari bahasa Yunani yaitu "astro" dan "nomos". Astro artinya bintang dan nomos artinya hukum. Astronomi ialah ilmu yang mempelajari benda-benda antariksa secara umum dan hukum-hukum yang berkaitan dengannya.

Bulan merupakan satelit atau benda angkasa yang mengelilingi bumi. Jaraknya dengan bumi adalah $240.000 \mathrm{mil}=384.000 \mathrm{~km}$. Bulan mempunyai garis tengah $2.160 \mathrm{mil}=3.456 \mathrm{~km}$. Pada permukaan bulan tedapat gunung-gunung dan dataran rendah seperti bumi. Lubang kpundannya tampak besaar-besar sampai ada yang bergaris tengah $8 \mathrm{~km}$. Berat jenis bulan kira-kira $1 / 2$ berat jenis

${ }^{21}$ Muhammad Ibn Isma'il al-Bukhari, Shahih al-Bukhari, tahqiq Musthafa Dib al-Bigha, (Beirut, Dar Ibn Katsir, 1987 M), Juz 2, h. 675.

${ }^{22}$ Departeman Pendidikan Nasional, Kamus Besar Bahasa Indonesia Pusat Bahasa, (Jakarta, Gramedia Pustaka Utama, 2012), Edisi keempat, h. 235. 
bumi. Berat jenis bumi -+ 5,52. Besarnya bulan hanya 1/82 bumi dan mempunyai gravitasi $1 / 6$ dari gravitasi bumi dan tidak ada atmosfir.

Sinar bulan adalah pantulan dari cahaya matahari. Bentuk dan ukuran bulan tidak berubah, yang berubah hanya penampakannya sesuai dengan bertambah dan bekurangnya permukaan yang tidak disinari matahari. Perubahan dalam penampakan bulan disebut FASA. Oleh karena itu, kita dapati istilah bulan sabit dan bulan purnama. Sebenarnya bulan bergerak dari barat ke timur mengelilingi bumi. Akan tetapi, sewaktu terbit dan tenggelam gerakannya seolah-olah dari timur ke barat. Ini disebabkan oleh putaran bumi lebih cepat daripada peredaran bulan mengelilingi bumi ${ }^{23}$.

\section{Ru'yah}

Makna ru'yah secara bahasa adalah melihat dengan mata kepala. Ru'yah yang dimaksud di sini adalah ru'yatul hilal, yảni melihat hilal secara langsung. Al-Qur'an tidak menjelaskan ru'yatul hilal, tetapi hadits banyak menjelaskan

Hadits-hadits Nabi yang menjelaskan ru'yah, antara lain sebagai berikut:

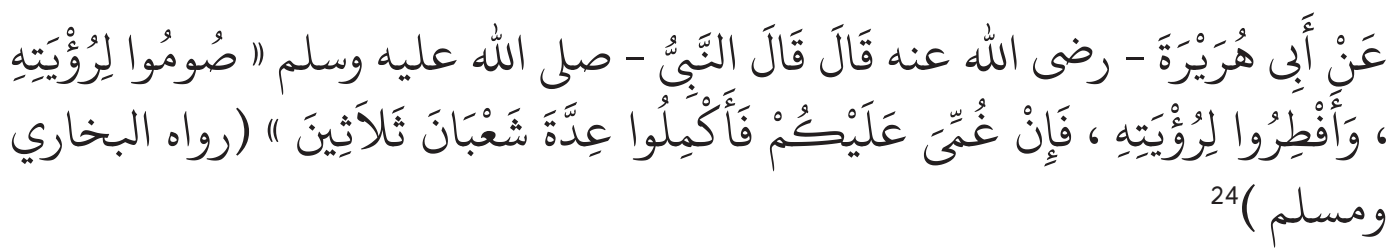

"Jika kalian melihatnya (hilal) maka berpuasalah dan jika kalian melihatnya (lagi) maka berbukalah(laksanakanlah idul fitri). Dan jika (pandangan) kalian terhalangi oleh awan maka sempurnakanlah bilangan bulan Sya'ban genap 30 hari." (H.R.Bukhari dan Muslim).

Juga hadits berikut :

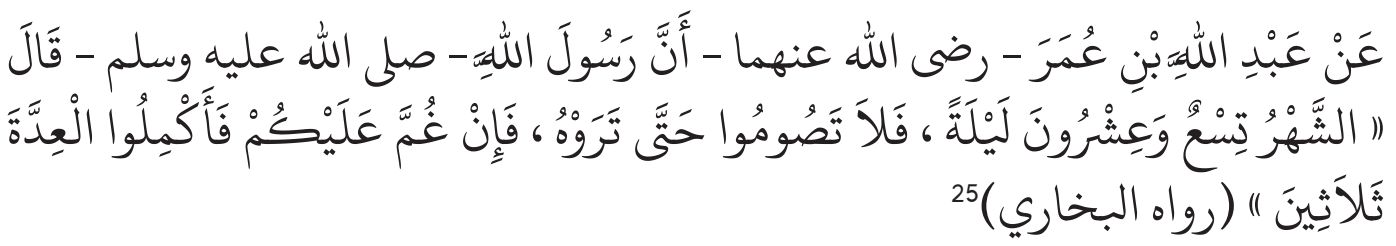

${ }^{23}$ Hariwijaya Soewandi dan Estu Sinduningrum, Ilmu Kealaman Dasar, (Bogor, Ghalia Indonesia, 2011) h. 106

${ }^{24}$ Muhammad Ibn Isma’il al-Bukhari, Shahih al-Bukhari, Beirut, Dar Ibn Katsir, 1987 M), Juz 2, h. 674. Muslim Ibn al-Hajjaj al-Naisaburi, Shahih Muslim, (Beirut, Dar Ihya' al-Turats al-Arabi, 1392 H), Juz 2, h. 762.

${ }^{25}$ Muhammad Ibn Isma'il al-Bukhari, Shahih al-Bukhari, Beirut, Dar Ibn Katsir, 1987 M), Juz 2, h. 674 . 
"Dari Abdullah bin Umar r.a., bahwa Rasulullah saw. brkata: bulan itu terdiri dari 29 malam, maka jangan kamu berpuasa sebelum melihat bulan (hilal). Dan jika (pandangan) kalian terhalangi oleh awan maka genapkanlah 30 hari." (H.R.Bukhari dan Muslim).

Juga hadits berikut :

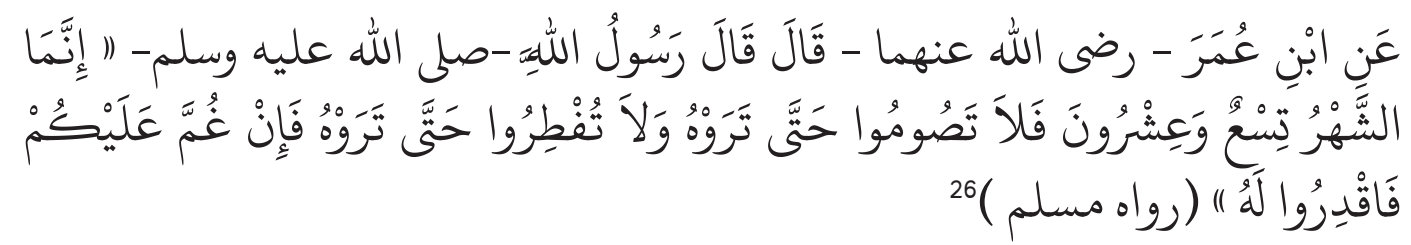

"Dari Ibn Umar r.a. berkata, Rasulullah saw. Bersabda: Sesungguhnya bulan itu 29 hari, maka janganlah kamu berpuasa sehingga kamu melihat hilal dan jangan kamu merayakan 'idul fitri sehingga kamu melihat hilal, apabila tertutup mendung maka sempurnakan bulan (menjadi 30 hari)" (H.R. Muslim)

Juga hadits berikut :

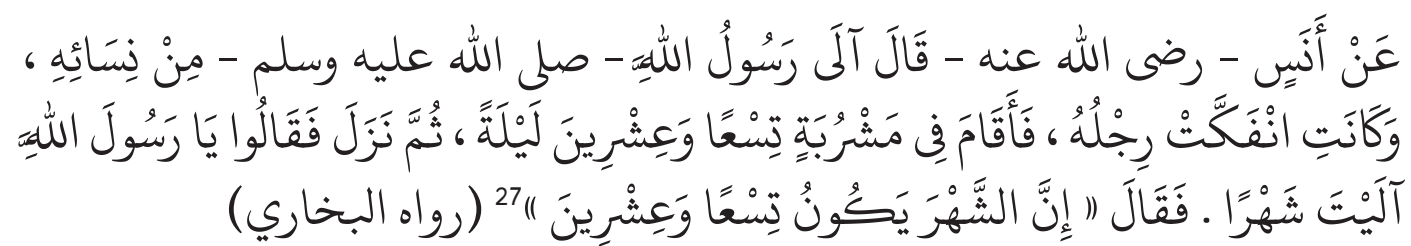

"Dari Anas r.a berkata: Rasulullah saw. Bersumpah untuk tidak menggauli istri-istrinya. Kakinya terpecah-pecah. Kemudian ia berdiam di kamarnya selama 29 malam. Kamudian ia keluar. Lalu para sahabat bertanya: wahai Rasulullah: bukankah engakau bersumpah 'Ila (tidak melakukan pya ersetubuhan dengan istri) selama satu bulan?. kemudian Rasulullah saw berkata: sesungguhnnya bulan ini terdiri dari 29 hari.(H.R. Bukhari)

Kemudahan melihat hilal dijelaskan dalam hadits berikut ini :

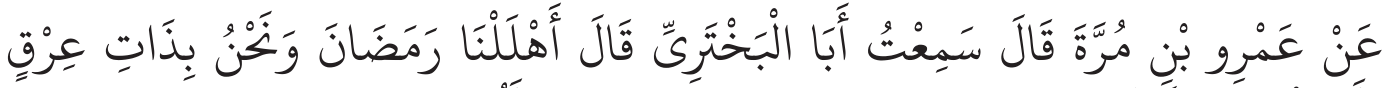

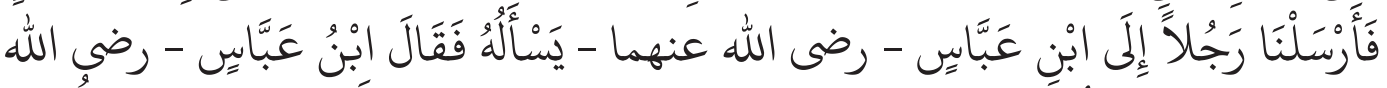

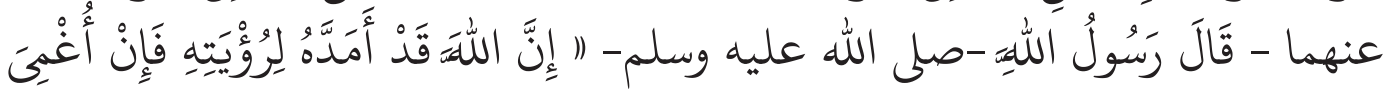

${ }^{26}$ Muslim Ibn al-Hajjaj al-Naisaburi, Shahih Muslim, (Beirut, Dar Ihya' al-Turats al-Arabi, 1392 H), Juz 5, h. 759.

${ }^{27}$ Muhammad Ibn Isma'il al-Bukhari, Shahih al-Bukhari, Beirut, Dar Ibn Katsir, 1987 M), Juz 2, h. 675. 


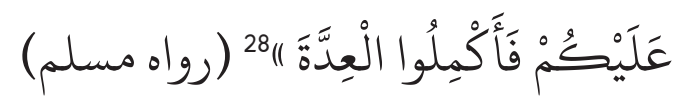

"Dari Amr Ibn Murrah berkata, saya mendengar Abu al-Bukhtari berkata: telah hilal bulan ramadhan sedang kami berada di dzat Irq, maka kami mengutus seseorang untuk datang kepada Ibnu Abbas r.a. menanyakan hal tersebut, maka Ibnu Abbas r.a. berkata: Rasulullah saw. Bersabda: "sesungguhnya Allah swt. telah memberikan kemudahan untuk melihat hilal, apabila tertutup awan, maka sempurnakanlah bilangan bulan (30 hari)" (H.R. Muslim)

\section{F. Tafsir Tekstual dan Kontekstual}

\section{a. Tafssir Tekstual}

Tafsir tekstual terdiri dari dua kata yaitu tafsir dan tekstual. Tafsir adalah ilmu yang yang digunakan untuk memahami al-Qur'an, menjelaskan maknanya, dan menggali hukum dan hikmahnya. ${ }^{29}$ Sedangkan tekstual yang berasal dari kata teks yang berarti naskah yang berupa kata-kata asli dari pengarang atau kutipan dari kitab suci untuk pangkal ajaran atau alasan atau bahan tertulis untuk dasar memberikan pelarajan, berpidato dan lain sebagainya. ${ }^{30}$

Maka dari itu, tafsir tekstual ialah suatu kecenderungan atau metode penafsiran al-Qur'an yang menitikberatkan pada makna teks secara harfiah (literal) dengan tanpa menyertakan konteks sosio-historis teks dalam aktivitas penafsirannya: di mana, kapan, dan mengapa teks tersebut lahir, dan bagaimana proyeksi makna teks ke depan. Karena, mengedapankan makna harfiah teks di satu sisi, dan menafikan peran keterlibatan sang penafsir di sisi lain, maka penetapan maknanya menjadi dominan otoritas teks. Di luar teks tidak ada makna yang bisa dipertanggungjawabkan dan diyakini maknanya. ${ }^{31}$

${ }^{28}$ Muslim Ibn al-Hajjaj al-Naisaburi, Shahih Muslim, (Beirut, Dar Ihya' al-Turats al-Arabi, 1392 H), Juz 2, h. 765.

${ }^{29}$ Badruddin az-Zarkasyi, Al-Burhan fi Ulum Al-Qur'an, (Beirut, Dar Ihya al-Kutub al-Arabiyah, 1376), Juz 1, h. 13. 2008), h. 561

${ }^{30}$ Tim Redaksi Kamus Bahasa Indonesia, Kamus Bahasa Indonesia (Jakarta; Pusat Bahasa,

${ }^{31}$ H. U. Syafrudin, Paradigma Tafsir Tekstual dan Kontekstual (Cet. 1; Yogyakarta: Pustaka Pelajar, 2009), h. 41-42.

136 Mumtäz Vol. 1 No. 2, Tahun 2017 


\section{b. Tafsir Kontekstual}

Secara etimologi, kata kontekstual berasal dari kata benda bahasa Inggris yaitu context yang di-indonesia-kan dengan kata "konteks". kata kontekstual memiliki dua arti, 1) Bagian suatu uraian atau kalimat yang dapat mendukung atau menambah kejelasan makna, 2) Situasi yang ada hubungannya dengan suatu kejadian. ${ }^{32}$ Dengan demikian, maka dapat dipahami bahwa kontekstual adalah menarik suatu bagian atau situasi yang ada kaitannya dengan suatu kata/kalimat sehingga dapat menambah dan mendukung makna kata/kalimat tersebut.

Adapun secara terminologi, kata kontekstual setidaknya memiliki tiga pengertian: 1) Upaya pemaknaan dalam rangka mengantisipasi persoalan dewasa ini yang umumnya mendesak, 2) Pemaknaan yang melihat keterkaitan masa lalu, masa kini, dan masa mendatang atau memaknai kata dari segi historis, fungsional, serta prediksinya yang dianggap relevan, 3) mendudukkan keterkaitan antara teks dan terapannya. ${ }^{33}$

Ahmad Syukri Saleh (lahir 1965) berpendapat bahwa tafsir kontekstual adalah menafsirkan al Qur'an berdasarkan pertimbangan analisis bahasa, latar belakang sejarah, sosiologi, dan antropologi yang berlaku dan berkembang dalam kehidupan masyarakat Arab pra-Islam dan selama proses wahyu al Qur'an berlangsung. Kemudian dilakukan penggalian prinsip-prinsip moral (spirit) yang terkandung dalam berbagai pendekatan tersebut. ${ }^{34}$

\section{G. Penafsiran Syahida, Ar-Ru'yah dan faqduru lah}

\section{a. Al-ru'yah}

Ulama pada umumnya atau sebagian besar, terutama ulama salaf, menafsirkan ru'yah yang terdapat dalam beberapa hadits nabi dengan penafsiran tekstual. Ibnu Hajar al-'Asqalani misalnya, menjelaskan ru'yah dalam hadits nabi "janganlah kamu berpuasa sebelum melihat hilal"

Para ahli tafsir dari kalangan fuqaha seperti imam madzhab yang empat Imam Hanafi, Maliki, Syafi'i, dan Hambali berpendapat bahwa ru'yah yang dimaksudkan adalah ru'yah bilbashar (dengan penglihatan mata), bahkan mereka tidak membenarkan penetapan hilal dengan menggunakan ilmu nujum atau

\footnotetext{
${ }^{32}$ Tim Penyusun Kamus Pusat Pembinaan dan Pengembangan Bahasa, Kamus besar Bahasa Indonesia (Jakarta: Balai Pustaka, 1988), Edisi II, hal. 458.

${ }^{33}$ Noeng Muhadjir, Metodologi Penelitian Kualitatif (Yogyakarta: Rake Sarasin, 2000), Edisi IV, hal. 263-264

${ }^{34}$ Ahmad Syukri Saleh, Metodologi Tafsir Kontemporer Fazlur Rahman (Jakarta: GP Press, 2007), 45-46
} 
hisab. dengan alasan bahwa hisab Imam Hanafi, misalnya, berpendapat bahwa ilmu miqat, hisab, dan nujum itu ketiga-tiganya sama tidak dapat dijadikan pedoman dalam menetapkan ru'yah hilal, dengan alasan bhwa hal itu betentangan dengan syariat $\mathrm{Nabi}^{35}$

\section{b. faqduru lah}

Telah terjadi perdebatan dalam masalah penetapan hilal ini sejak akhir abad pertama hijriyah, ya'ni pada masa tabi'in . kajian ini muncul disebabkan adanya lafazh yang musykil dalam hadits Nabi,yaitu lafazh faqduru lah

Di dalam hadits Nabi yang diriwayatkan oleh Imam Bukhari dan Muslimberikut ini trdapat kata faqduru lah

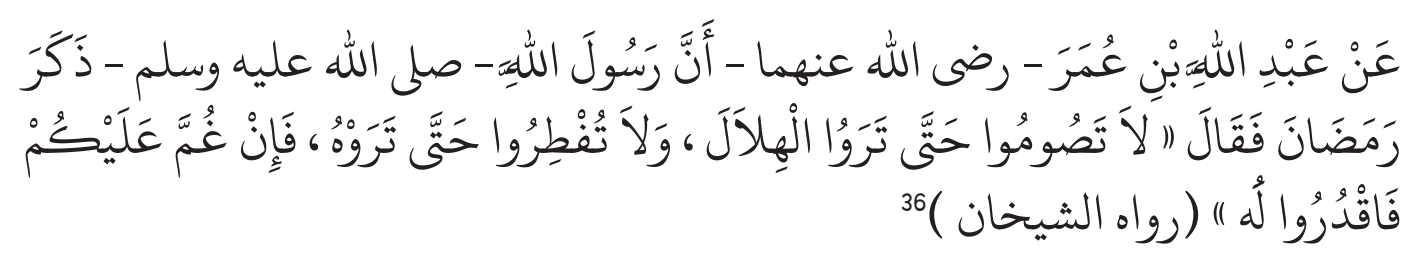

Dari Abdullah Ibn Umar r.a. Rasulullah saw. Menjelaskan Ramadhan,maka ia berkata :"Kalau kalian melihat hilaal (awal Ramadhan, -pent) maka berpuasalah, dan jika kalian melihatnya (hilal tanda masuk bulan Syawwal) maka berbukalah (idul fitri). Dan jika (pandangan) kalian terhalangi oleh awan, maka hendaklah kalian menghitungnya!" (Diriwayatkan oleh Imam Al-Bukhari, Muslim dan An-Nasa’i)

Ulama berbeda pendapat di dalam menafsirkan kata faqduru lah,

\section{Ulama yang membolehkan penggunaan hisab:}

Dengan kata faqduru lah maka mengandung ma’na memperkirakan dan menghitung ketinggian hilal dengan hisab falaki (ilmu hisab). Pendapat ini disandarkan kepada Mutharrif Ibn Abdillah Ibn al-Syikhkhir dari kalangan tabi'in, Abu al-Abbas Ibn Suraij dari pengikut mazhhab Syafi'i dan Ibn Qutaibah dari ulama ahli hadits. Ibn Ar-Rusyd meriwayatkan pendapat Mutharrif :apabila terjadi mendung maka hilal ditetapkan dengan perbintangan, rotasi bulan dan cara hisab. Pendapat seperti ini juga diriwayatkan dari asy-Syaf'i dalam satu riwayat. Sedangkan Ibn Suraij menafsirkan hadits Nabi "faqduru lah", bahwa kata ini

\footnotetext{
${ }^{35}$ Wahbah Al-Zuhaili, al-Fiqh al-Islami wa adillatuh, (Damaskus, Dar al-Fikr, tth), Juz 3, h. 33

${ }^{36}$ Muhammad Ibn Isma'il al-Bukhari, Shahih al-Bukhari, (Beirut, Dar Ibn Katsir, 1987 M), Juz 2, h. 674
} 
dikhususkan kepada orang yang diberikan kemampuan ilmu hisab, sedangkan dalam hadits yang lain menggunakan kata "'faakmilu al-iddah"(sempurnakan bilangan bulan sy'ban)ini ditujukan kepada umum. Ibn Ash-Shalah mengomentari pendapat Ibn Suraij: bahwa yang dimaksud Ibn Suraij tentang pengetahuan hisab: bahwa mengetahui rotasi bulan berarti mengetahui jalannya hilal.

Sebagian madzhab hanafi berpendapat: boleh berpedoman kepada pendapat ahli perbintangan. Al-Qarafi menyebutkan satu pendapat bagi madzhab maliki (almalikiyah), bahwa boleh menggunakan pedoman hisab dalam menetapkan hilal.

Al-Qalyubi dari asy-Syafi'iyah meriwayatkan pendapat Al-'Abbadi :apabila hisab secara pasti menunjukkan tidak terjadi ru'yah hilal, maka ucapan orang yang adil tentang terjadinya ru'yah tidak boleh diterima, dan ditolak persaksiannya. Ini adalah jelas, tidak boleh berpuasa saat itu, orang yang melawan penetapan ini adalah kesombongan.

Imam Ibn As-Subki berpendapat, bahwa ilmu hisab bisa dijadikan pedoman dalam penetapan hilal dan waktu shalat.karena hisab adalah qath'i (pasti). ${ }^{37}$

\section{Pendapat yang tidak membenarkan penggunaan hisab:}

Dari kalangan madzhab Syafi'i (Asy-Syafi'yah), Imam An-Nawawi berpendapat: tidak boleh berpuasa bulan Ramadhan sebelum masuk bulan, masuk bulan diketahui dengan melihat hilal. Apabila cuaca mendung maka bulan Sya'ban disempurnakan 30 hari. ${ }^{38}$

Kata syahida pada ayat tersebut, ditafsirkan 'siapa yang hidir di antara kamu pada bulan ramadhan, maksudnya adalah ; sedang tidak musafir (bepergian)' atau ditafsirkan 'siapa yang mengetahui (menyaksikan) hilal bulan ramadhan (pada saat itu) dengan cara apapun, maka hendaknya ia melaksanakan ibadah puasa. ${ }^{39}$ Sebagian ulam fiqih kontemporer berpendapat, bahwa melihat hilal dengan mata tidaklah akurat, sedangkan ilmu falak telah mengalami kemajuan yang pesat, juga sudah al-Haiah al-Amah al-Mishriyah, sangat dimungkinkan perhitungan waktu dengan ilmu falak lebih akurat, sebagaimana perhitungan waktu shalat yang telah menjadi pedoman. ${ }^{40}$

\footnotetext{
${ }^{37}$ Organisasi Muktamar Islam Jeddah, Majallah majma’ al-Fiqh al-Islamai,Juz 3,h. 359.

${ }^{38}$ Wuzarah al-Auqaf wa Asy-Sy'un al-Islamiyah, al-Mausu'ah al-Fiqhiyah al-Kuwaitiyah, (Kuwait, Dar aSh-Shafwah, 1427), Juz 32, h. 22.

${ }^{39}$ Majmu'ah mi al-Ulama' bi Isyraf Majma' al-Buhuts al-Islamiyah bi al-Azhar, at-Tafsir al-Wasith, ( ttp, al-Haiah al-'ammah li syu'un al-Mathabi' al-Amiriyah, 1393 H), Cet. Ke-1, Juz 1, h. 286. al-Wasith.

${ }^{40}$ Majmu’ah min al-Ulama’ bi Isyraf Majma’ al-Buhuts al-Islamiyah bi al-Azhar, at-Tafsir
} 
Muhammad Abduh menafsirkan ayat ini, bahwa yang dimaksud syahid atau hadir pada bulan ramadhan itu berarti dengan melihat hilal, maka bagi siapa saja yang melihat hilal secara langsung atau mengetahui dari orang lain melihat hilal, wajib melaksanakan puasa. ${ }^{41}$ Banyak di antara ulama, yang menafsirkan secara tekstual terhadap ayat dan hadits yang terkait dengan ru'yah. Penafsiran tekstual pada kata ru'yah yang terdapat pada hadits-hadits Nabi inilah yang menyebabkan terjadinya perbedaan dalam penetapan awal bulan hijriyah. Namun secara faktual banyak juga ulama yang menafsirkan ayat-ayat dan hadits secara kontekstual, yảni penafsiran yang disesuaikan dengan kondisi masa sekarang. Penafsiran ulama tentang waktu shalat, misalnya, ulama menafsirkannya secara kontekstual. Waktu shalat sudah terjadwal dan ditentukan sebelumnya sesuai ilmu hisab dan falak, bukan setiap kali mau melaksanakan shalat melihat posisi matahari.

\section{H. Kesimpulan}

1. Perputaran bulan dan matahari adalah merupakan fonomena alam (sains) yang setelah diteliti ternyata terjadi dan dapat dihitung secara pasti.

2. Menyatukan Perbedaan dalam penetapan Awal bulan Hijriyah adalah merupakan hal yang mendesak untuk dilakukan.

3. Perbedaan pendapat dalam penafsiran al-Quran dan Hadits adalah merupakan sunnatullah, hal ini dibuktikan adanya lafazh yang zhanni ad-dalalah. Perbedaan pendapat dalam pengamalan nilai-nilai al-Qur'an yang sifatnya individual nampaknya tidak menjadi masalah, tetapi ketika pengamalan nilai agama itu berdampak sosial seperti pelaksanaan shalat 'idul fitri dan idul adhha, maka hal ini sangat mengganggu keharmonisan dalam bermasyarakat, maka sebaiknya dipersatukan.

\section{Daftar Pustaka}

Abu Muhammad Al-Husain Ibn Mas'ud Al-Baghawi, Ma'alim al-Tanzil, (Beirut, Dar Tahayyibah, 1997 M)

Abu Zakaria Yahya Ibn Syaraf al-Nawawi, Syarh Shahih Muslim, (Beirut, dar Ihya' al-Turats al-Arabi, $1392 \mathrm{H}$ )

Al-Kholil Ibn Ahmad, Al-'Ain

Al-Razi, Mukhtar al-Shihah, (Beirut, Maktabah Lubnan Nasyirun, 1415)

As-Suyuthi, ad-durr al-mantsur fi at-ta'wil bi al-ma'tsur, ( Beirut, Dar al-Fikr, 1993)

${ }^{41}$ Muhammad Rosyid ibn Ali Ridho al-Husaini, Tafsir al-Manar, (Al-Haiah al-Ammah al-Mishriyah li al-Kitab, 1990 M), Juz 2, h. 130. 
Caner Taslaman, Miraccle of The Qur'an, terj. Ary Nilandari, (Bandung, Mican Pustaka, 2010)

Departeman Pendidikan Nasional, Kamus Besar Bahasa Indonesia Pusat Bahasa, (Jakarta, Gramedia Pustaka Utama, 2012), Edisi keempat.

Fakhruddin al-Razi, Mafatih al-Ghaib, (Beirut, Dar al-Fikr, tth)

Hariwijaya Soewandi dan Estu Sinduningrum, Ilmu Kealaman Dasar, (Bogor, Ghalia Indonesia, 2011)

Ibn Hajar Al-Asqalani, Ftah al-Bari Syarh Shahih al-Bukhari, (Beirut, Dar al-Ma'rifah, 1379)

Ibn Jarir Al-Thabari, Jami' al-Bayan fi Ta’wil al-Quran, ( Muassasah al-Risalah, 1420)

Ibrahim Mushthafa dkk, al-Mu'jam al-Wasith, al-Maktabah al-Syamilah

Muhammad Ibn Abdurrahman al-Sakhawi, al-Maqashid al-Hasanah fi Bayan Katsir mi al-Ahadits al-Musytahirah 'ala al-Alsinah, (Beirut, Dar al-Kitab al-Arabi )

Muhammad Ibn Isma'il al-Bukhari, Shahih al-Bukhari, (Beirut, Dar Ibn Katsir, $1987 \mathrm{M})$

Muslim Ibn al-Hajjaj al-Naisaburi, Shahih Muslim, (Beirut, Dar Ihya al-Turats al-Arabi, tth)

Rinto Anugraha, Pengantar Ilmu Hisab, http://rukyatulhilal.org/artikel/rinto-pengantar-ilmu-hisab.html diakses tgl 23-09-2011

Muhammad Ibn Isma'il al-Bukhari, Shahih al-Bukhari, (Beirut, Dar Ibn Katsir, 1987 M)

Muhammad Ibn Isma'il al-Bukhari, Shahih al-Bukhari, tahqiq Musthafa Dib al-Bigha, (Beirut, Dar Ibn Katsir, 1987 M)

Murtadha Al-Zabidi, Taj al-Arus min Jawahir al-Qamus, (Darul Hidayah, th)

Muhammad Ibn Isma'il al-Bukhari, Shahih al-Bukhari, (Beirut, Dar Ibn Katsir, $1987 \mathrm{M})$

Muhammad Ibn Isma'il al-Bukhari, Shahih al-Bukhari, tahqiq Musthafa Dib al-Bigha, (Beirut, Dar Ibn Katsir, 1987 M)

Muhammad Ibn Isma’il al-Bukhari, Shahih al-Bukhari, Beirut, Dar Ibn Katsir, 1987 M)

Muslim Ibn al-Hajjaj al-Naisaburi, Shahih Muslim, (Beirut, Dar Ihya' al-Turats al-Arabi, $1392 \mathrm{H}$ )

Muhammad Ibn Isma’il al-Bukhari, Shahih al-Bukhari, Beirut, Dar Ibn Katsir, 1987 M)

Muslim Ibn al-Hajjaj al-Naisaburi, Shahih Muslim, (Beirut, Dar Ihya' al-Turats al-Arabi, $1392 \mathrm{H}$ ) 
Muhammad Ibn Isma’il al-Bukhari, Shahih al-Bukhari, Beirut, Dar Ibn Katsir, 1987 M)

Muslim Ibn al-Hajjaj al-Naisaburi, Shahih Muslim, (Beirut, Dar Ihya' al-Turats al-Arabi, $1392 \mathrm{H}$ )

Muhammad Sayyid Thanthawi, at-Tafsir al-Wasith

Muhammad Ibn Isma’il al-Bukhari, Shahih al-Bukhari, Beirut, Dar Ibn Katsir, $1987 \mathrm{M})$

Sulaiman Ibn Al-Asy'ats Abu Daud, Sunan Abu Daud, (Beirut, Darul Fikr, tth)

Wuzarah al-Auqaf wa Asy-Sy'un al-Islamiyah, al-Mausu'ah al-Fiqhiyah al-Kuwaitiyah, (Kuwait, Dar aSh-Shafwah, 1427) 